\title{
ANALISIS KINERJA SEKTOR PERTANIAN DALAM UPAYA PENGENTASAN KEMISKINAN DI NUSA TENGGARA BARAT PADA PERIODE 2008-2018
}

\section{PERFORMANCE ANALYSIS OF AGRICULTURE SECTOR IN ALLEVIATING POVERTY ON WEST NUSA TENGGARA, 2008-2018}

\author{
Oleh Rosiady H. Sayuti ${ }^{1}$ dan Moh. Taqiuddin ${ }^{2}$ \\ 1) Program Studi Agribisnis Fakultas Pertanian, Universitas Mataram; ${ }^{2}$ ) Laboratorium Sosial Ekonomi \\ Peternakan, Fakultas Peternakan - Universitas Mataram \\ sayuti@unram.ac.id
}

\begin{abstract}
ABSTRAK
Badai krisis ekonomi 1997/1998 telah menyebabkan peningkatan cukup besar jumlah penduduk miskin NTB yakni dari 17,61 persen (1996) melonjak menjadi 32,96 persen (1999) meskipun terus mengalami penurunan pada tahun-tahun berikutnya hingga mencapai 23,99 persen di akhir tahun 2007. Pada periode berikutnya, prosentase kemiskinan terus mengalami penurunan meskipun angka-angkanya selalu berada di atas rata-rata nasional. Dalam kurun waktu 2008-2018, jumlah penduduk miskin NTB menurun sebesar 9,06 persen dari 23,81 (2008) menjadi 14,75 persen (2018). Penurunan angka kemiskinan tersebut dimungkinkan karena adanya terobosan Pemerintah Propinsi NTB melalui berbagai program-program pengentasan kemiskinan berbasis pada inisiatif dan sumberdaya lokal serta didukung oleh kreatifitas kolektif dengan tetap bertumpu pada sektor pertanian. Implementasi program-program pengentasan kemiskinan tersebut menerapkan strategi percepatan, inovasi, dan pertambahan nilai pada komoditas-komoditas unggulan lokal. Artikel ini mendeskripsikan dan menganalisis kinerja sektor pertanian terutama produksi tanaman pangan (padi, jagung, dan kedelai) dikaitkan dengan kondisi makro ekonomi daerah terutama kontribusi sektor pertanian pada struktur Produk Domestik Regional Bruto (PDRB) 2008-2018, Nilai Tukar Petani (NTP), dan angka kemiskinan penduduk. Data dan informasi dikumpulkan melalui desk-review terhadap data sekunder yang bersumber dari Badan Pusat Statistik serta dianalisis menggunakan aplikasi MS Excel dan SPSS 16.0. Kesimpulan hasil analisis data sekunder ini adalah kinerja sektor pertanian dalam hal pengentasan kemiskinan ditunjukkan dengan NTP makin meningkat dalam kurun waktu 2008-2013 sebagai implikasi dari peningkatan produksi sejumlah komoditas unggulan subsektor pertanian tanaman pangan.

Kata kunci: kinerja, sektor pertanian, nilai tukar petani, kemiskinan,
\end{abstract}

\section{ABSTRACT}

The economic crisis on the 1997/1998 has caused significantly increase in the number of poor people in NTB, from 17.61 percent (1996) to 32.96 percent (1999) although it continued to decline in the subsequent years to 23.99 percent at the end in 2007. In the following period, the percentage of poverty continued decline even though the numbers of its are always above of national average. In the period of 2008-2018, the number of poor people had decreased by 9.06 percent from 23.81 (2008) to 14.75 percent (2018). The decreasing of poverty rates was enabled by the breakthrough of the NTB Provincial Government through various poverty reduction programs based on local initiatives and resources as well as supported by collective creativity with focus on the agricultural sector. The poverty reduction programs was implemented by strategy of acceleration, innovation, and value added in local superior commodities. This article describes and analyzes the performance of agricultural sector, especially production of three food crops (rice, corn, and soybeans) associated with the macroeconomic conditions that include contribution of the agricultural sector to Gross Regional Domestic Product (PDRB) 20082018, Farmers Exchange Rate (NTP), and poverty rate of population. The data and information were collected by desk-review of secondary data from the Central Statistics Agency and analyzed using MS Excel and SPSS 16.0. The conclusion of this analysis is the performance of the agricultural sector in poverty reduction is shown by increasing NTP in the period of 2008-2013 as an implication of increasing production of local superior commodities in sub-sector of food crops.

Kata kunci: kinerja, sektor pertanian, nilai tukar petani, kemiskinan,

Keywords: performance, agricultural sector, farmer exchange rate (NTP), poverty 


\section{PENDAHULUAN}

Kemiskinan merupakan masalah utama dalam pembangunan ekonomi Indonesia sejak era 1970-an ketika masa Orde Baru hingga saat sekarang ini sehingga topik-topik terkait isu ini selalu aktual untuk dibahas. Upaya pengentasannya selalu menjadi prioritas utama Pemerintah dari masa ke masa agar tidak berimplikasi luas bagi stabilitas kehidupan berbangsa dan bernegara. Hal ini dimungkinkan karena kegagalan mengatasi kemiskinan ini menurut Purwanto (2007) akan memicu munculnya berbagai persoalan di bidang sosial, ekonomi, dan politik di tengah-tengah masyarakat. Dalam Tujuan Pembangunan Berkelanjutan (TPB) atau Sustainable Development Goals (SDGs) 2015-2030, penurunan kemiskinan menjadi tujuan pertama dengan penekanan pada pentingnya komitmen global untuk mengakhirinya dalam dalam bentuk apapun. Todaro dkk (2015) menjelaskan bahwa kemiskinan merupakan masalah multidimensi dengan keterkaitan erat satu sama lain dengan berbagai aspek kehidupan manusia, baik ekonomi, politik, sosial budaya, psikologi, teknologi, dan lainnya. Oleh karenanya, upaya pengentasan kemiskinan membutuhkan waktu, strategi, inovasi, dan sumber daya serta sinerjisitas antar berbagai komponen.

Pemahaman tentang kemiskinan termasuk kaitannya dengan cara pengukurannya terus mengalami perkembangan (Yulaswati dkk, 2018). Khususnya kemiskinan wilayah perdesaan misalnya, Robert Chambers (1984) mengemukakan bahwa kemiskinan merupakan klaster dari adanya keterkaitan satu sama lain dari berbagai kondisi kurang menguntungkan dan menyebabkan seseorang terperangkap serta sulit keluar dari kondisi kemiskinan. Kondisi kurang menguntungkan tersebut meliputi kelemahan fisik, kerentanan terhadap guncangan, keterisolasian, ketidakberdayaan, dan kemiskinan itu sendiri. Definisi kemiskinan tidak lagi terbatas pada aspek ekonomi atau penurunan pendapatan semata melainkan jauh lebih luas lagi sebagaimana Bank Dunia (2001) berikut ini:

"Poverty is hunger. Poverty is lack of shelter. Poverty is being sick and not being able to go to school and not knowing to know how to read. Poverty is not having job, is fear for the future, living one day at a time. Poverty is losing a child to illness bring about by unclean water. Poverty is powerlessness, lack of representation and freedom"

Dari pandangan Bank Dunia (2001) di atas dapat dijelaskan bahwa kemiskinan terkait dengan kerentanan dan ketiadaan akses terhadap layanan-layanan dasar sesuai dengan hak dalam aspek: pangan, perumahan, pendidikan, kesehatan, partisipasi dalam pengambilan keputusan, dan kebebasan.

Berbagai intervensi kebijakan dan program pengentasan kemiskinan telah berkontribusi nyata pada penurunan angka kemiskinan di Indonesia, dari 60 persen pada tahun 1970 hingga menembus angka satu digit yakni 9,82 persen (Maret 2018) dan turun kembali menjadi 9,66 persen (September 2018). Namun demikian, jumlah penduduk miskin di Indonesia secara absolut masih cukup tinggi yaitu 25,95 juta penduduk pada September 2018. Dari jumlah tersebut, BPS (2018) mencatat 61,32 persen di antaranya bertempat tinggal di wilayah perdesaan dan umumnya bekerja pada sektor pertanian. Hal ini menunjukkan bahwa masalah kemiskinan di Indonesia merupakan permasalahan dominan di daerah perdesaan. Ditinjau dari aspek sebaran berdasarkan kawasan, propinsi-propinsi Kawasan Timur Indonesia (KTI) memiliki angka kemiskinan relatif lebih tinggi dibandingkan propinsi-propinsi di Kawasan Barat Indonesia (KBI). Nusa Tenggara Barat (NTB) merupakan salah satu propinsi di Kawasan Timur Indonesia dengan prosentase penduduk miskin selalu berada di atas rata-rata nasional (Sayuti, 2017).

Krisis ekonomi 1997/1998 telah berimplikasi luas bagi melonjaknya jumlah penduduk miskin NTB yakni dari 17,61 persen (1996) hingga lebih dari 45 persen (1997 dan 1998) serta menurun secara signifikan menjadi 32,96 persen (1999). Pada kurun waktu 1999-2007, prosentase penduduk miskin NTB menurun sekitar 8,97 persen jika merujuk pada angka kemiskinan tahun 2007 mencapai 23,99 persen. Selanjutnya, penduduk miskin NTB terus mengalami penurunan secara konsisten dari tahun ke tahun selama kurun waktu 2008-2018 hingga mencapai angka 9,06 \% yakni dari 23,81 (2008) menjadi 14,75 persen (2018). Bahkan, penurunan angka kemiskinan selama 2013-2017 sebesar 1,97 persen telah mengukuhkan NTB menempati peringkat kedua setelah Papua Barat (1,98 persen) sebagai propinsi paling progresif dalam hal mengurangi angka kemiskinan secara nasional. Saat itu, penurunan angka kemiskinan secara nasional pada kurun waktu tersebut mencapai 1,25 persen dari 11,37 persen (2013) menjadi 10,12 persen (2017). Keberhasilan penurunan angka kemiskinan tersebut dimungkinkan karena Pemerintah Propinsi NTB memiliki inisiasi-inisiasi melalui berbagai program unggulan berbasis pada pemanfaatan sumberdaya lokal (Sayuti, 2017). Dalam analisisnya, Yulaswati dkk (2018) telah menyimpulkan bahwa setiap propinsi memiliki kapasitas berbeda dalam upaya penurunan angka kemiskinan selama kurun waktu 2013-2017 tersebut. Sejalan dengan pandangan Yulaswati dkk (2018), argumentasi artikel ini adalah kebijakan pengentasan kemiskinan tidak harus bersifat seragam namun 'beragam' dengan memperhatikan kondisi wilayah, kebutuhan masyarakat, dan karakteristik dari faktor penyebabnya masing-masing sehingga penyelesaian persoalannya menjadi lebih fokus.

Pada kurun waktu 2008-2018, Pemerintah Propinsi NTB banyak melakukan terobosan-terobosan inovatif di bawah kepemimpinan Tuan Guru Bajang (TGB) sebagai seorang tokoh muda dari kalangan Pondok Pesantren. Karakteristik program unggulan pengentasan kemiskinan Pemerintah Propinsi NTB menyentuh basis penghidupan sebagian besar penduduknya yakni sektor pertanian di wilayah-wilayah perdesaan melalui strategi 
percepatan, inovasi, dan pertambahan nilai (PIN) terhadap komoditas-komoditas unggulan (tanaman pangan, peternakan, dan perikanan). Pilihan strategi PIN berbasis komoditas pertanian tersebut cukup beralasan mengingat struktur perekonomian daerah NTB masih bertumpu pada kinerja sektor pertanian. Rata-rata pertumbuhan ekonomi NTB (tanpa sektor tambang) selama kurun waktu 2008-2018 sebesar 6,1 persen. Sementara, rata-rata pertumbuhan sektor pertanian, kehutanan, dan perikanan mencapai angka 3,7 persen (Herbawati, 2018).

Artikel ini menganalisis kinerja sektor pertanian sebagai basis utama pengentasan kemiskinan penduduk NTB selama kurun waktu 2008-2018 dari data-data sekunder dengan fokus pada capaian produksi tiga komoditas unggulan tanaman pangan yakni padi, jagung, dan kedelai. Pertanyaan pokok dalam artikel ini adalah sejauhmana kinerja sektor pertanian memiliki kontribusi terhadap Nilai Tukar Petani (NTP) dan penurunan angka kemiskinan penduduk selama kurun waktu 2008-2018? Untuk menjawab pertanyaan tersebut artikel ini menampilkan trend produksi ketiga komoditas, nilai tukar petani, dan laju penurunan angka kemiskinan penduduk NTB dalam kurun waktu sepuluh tahun terakhir atau masa kepemimpinan TGB selama dua periode pemerintahan.

\section{METODE PENELITIAN}

Penelitian ini menggunakan metode desk-review dengan mengacu pada definisi menurut Hague dkk (2013) yakni pengumpulan data sekunder atau data-data yang telah dikumpulkan sebelumnya tanpa melakukan survei lapangan. Lebih lanjut, Hague dkk (2013) menjelaskan bahwa publikasi data statistik merupakan salah satu sumber data penting bagi penelitian-penelitian dengan metode desk-review. Adapun jenis data yang dikumpulkan dalam penelitian ini berupa publikasi data statistik oleh Badan Pusat Statistik (BPS) selama kurun waktu 2008-2018 berupa: produksi panen tiga komoditas tanaman pangan (padi, jagung, dan kedelai); nila tukar petani (NTP); prosentase penduduk miskin; kontribusi sektor pertanian terhadap struktur PDRB NTB; laju pertumbuhan sektor pertanian; dan laju pertumbuhan ekonomi NTB.

Data-data sekunder dari publikasi statistik selama 2008-2018 dianalisis dengan langkah-langkah sebagaimana penjelasan Martono (2011), sebagai berikut: pengolahan data menggunakan Microsoft Excel Windows 10.0 dan SPSS 16.0; penyajian data dalam bentuk grafik garis (line chart) dan grafik batang (bar chart); interpretasi hasil pengolahan dan penyajian data secara deskriptif.

\section{HASIL DAN PEMBAHASAN}

\section{Struktur Perekonomian Propinsi Nusa Tenggara Barat}

Proses pembangunan daerah dari waktu ke waktu bisa berakibat pada terjadinya pergeseran struktur perekonomian yang dicerminkan dari kontribusi masing-masing sektor terhadap nilai Produk Domestik Regional Bruto (PDRB). Hal ini ditunjukkan dari pergeseran basis dari struktur perekonomian NTB selama periode waktu 2008-2018 sebagaimana Gambar 1.:

Gambar 1. Perbandingan Kontribusi Sektor Terhadap PDRB NTB

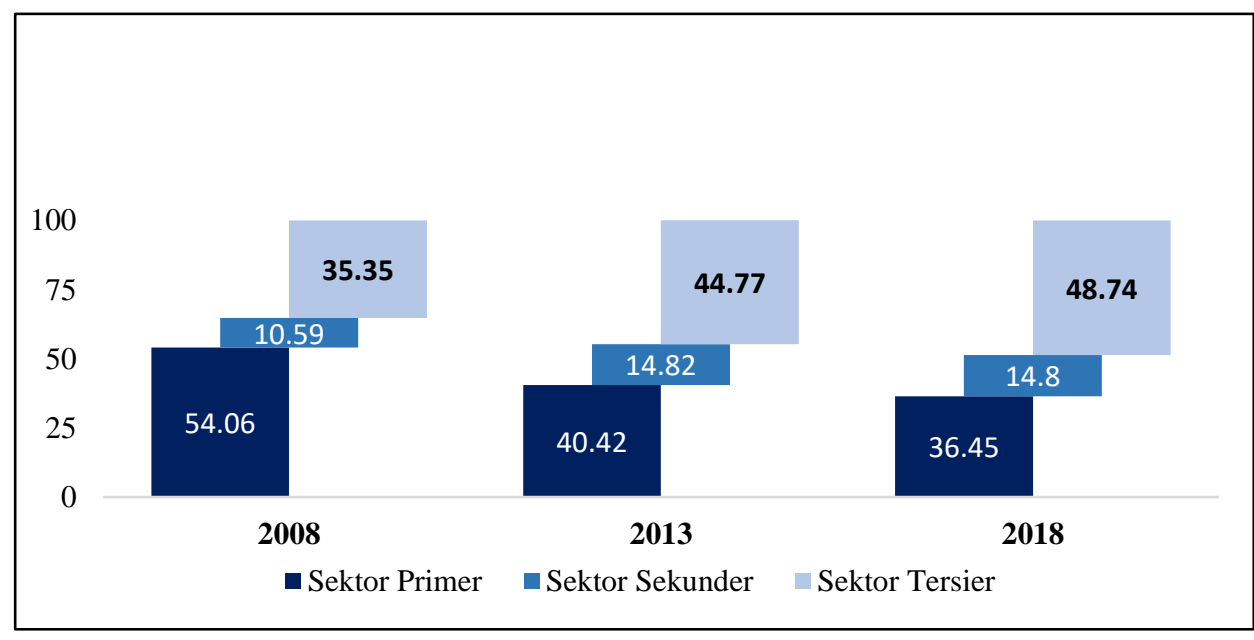

Sumber: BPS NTB (2008-2018)

Pada tahun 2008, struktur perekonomian NTB masih didominasi oleh sektor-sektor primer (sektor pertanian; sektor pertambangan dan penggalian) dengan kontribusi mencapai 54,06 persen dari total PDRB NTB. Namun demikian, seiring dengan makin menurunnya kinerja sektor pertambangan dan penggalian (khususnya sub pertambangan bijih logam) maka kontribusi sektor-sektor primer mulai menurun menjadi 40,42 persen dan dominasinya terhadap struktur perekonomian NTB digeser oleh sektor tersier dengan kontribusi 44,77 persen. Kondisi ini terus berlanjut hingga tahun 2018 dengan dominasi sektor tersier (sektor perdagangan, hotel, dan restoran; sektor pengangkutan dan komunikasi; sektor lembaga keuangan; usaha persewaan dan jasa perusahaan; 
serta sektor jasa-jasa) makin menguat yakni 48,74 persen dibandingkan sektor primer (36,45 persen) dan sektor sekunder (sektor industri; listrik, gas dan air bersih; serta sektor bangunan pada angka 14,18 persen). Jika ditelusuri secara lebih seksama, kontribusi sektor-sektor primer terhadap PDRB NTB selama tiga poin waktu seperti tertera pada grafik 1. di atas sebagian besar disumbangkan oleh sektor pertanian, kehutanan, dan perikanan. Artinya, sektor pertanian masih menjadi basis perekonomian NTB jika dilihat dari kontribusi masing-masing sektor tanpa pengelompokkan ke dalam primer, sekunder, atau tersier sebagaimana Gambar 2.

Gambar 2. Kontribusi Masing-Masing Sektor Terhadap PDRB NTB

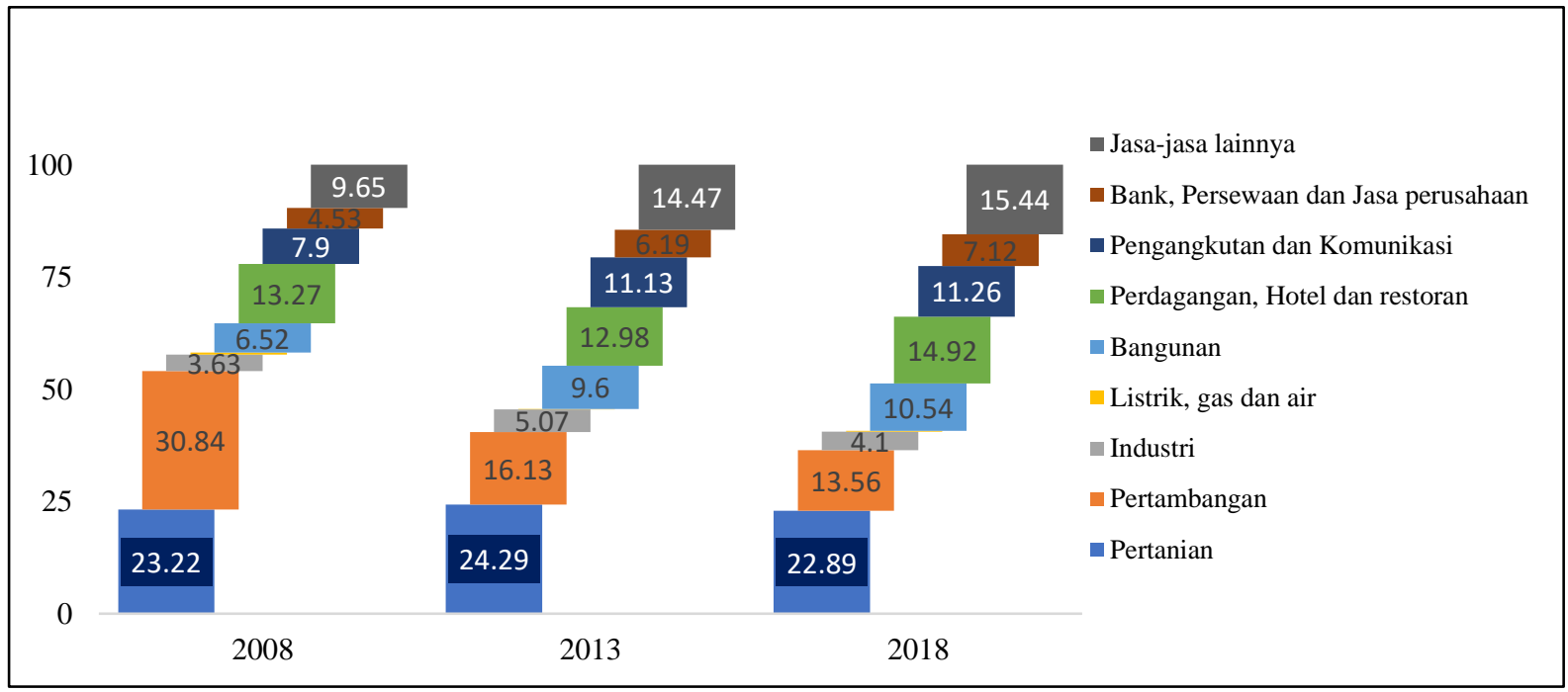

Sumber: BPS NTB (2008-2018)

\section{Pertumbuhan Sektor Pertanian}

Dalam kurun waktu 2008-2018, kontribusi sektor pertanian (dalam arti luas) terhadap pembentukan PDRB NTB cenderung fluktuatif sebagai implikasi dari fluktuasi laju pertumbuhannya. Atas Dasar Harga Konstan (ADHK) 2010, nilai rata-rata pertumbuhan mencapai 3,7 persen per tahun. Angka pertumbuhan tertinggi dicapai pada tahun 2015 (6,9 persen) dan terendah tahun 2010 (1,1 persen). Fluktuasi dari laju pertumbuhan dimungkinkan karena kinerja produksi komoditas pertanian (dalam arti luas) juga berfluktuasi sebagai akibat dari perubahan berbagai faktor produksi. Sebagai basis dari perekonomian NTB, trend pertumbuhan sektor pertanian (dalam arti luas) ini berkontribusi pada pola pertumbuhan ekonomi daerah sebagaimana terlihat pada gambar 3 di bawah.

Gambar 3. Kontribusi dan Laju Pertumbuhan Sektor Pertanian, 2008-2018

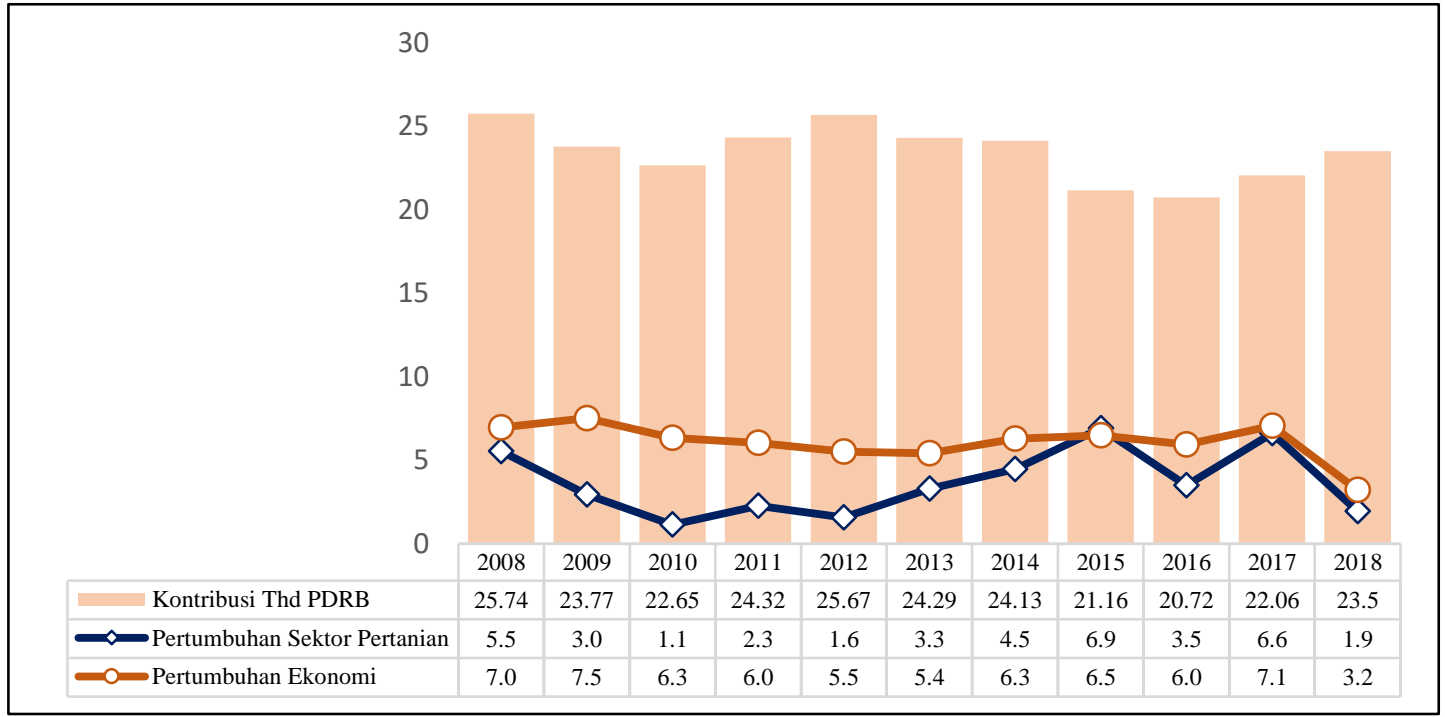

Sumber: BPS NTB (2008-2018)

Kinerja Produksi Komoditas Unggulan Tanaman Pangan 
Padi, jagung dan kedelai merupakan komoditas unggulan yang dihasilkan oleh subsektor pertanian di Provinsi NTB. Hal ini disebabkan karena produktivitasnya tinggi, pangsa pasar makin meluas dan memiliki nilai ekonomis terus meningkat dari tahun ke tahun. Dalam kurun waktu 2008-2018, pola produksi padi cenderung meningkat dengan produksi rata-rata mencapai 2.136,9 (x 000) ton per tahun. Sedangkan, peningkatan produksi komoditas jagung terlihat sangat drastis dari 196,3 (x 000) ton pada tahun 2008 hingga 2.084,9 (x 000) ton atau lebih dari 10 kali lipat dengan rata-rata produksi sekitar 925,8 (x 000) ton per tahun. Lonjakan peningkatan produksi jagung dalam 10 tahun terakhir terkait erat dengan ditetapkannya komoditas ini menjadi sasaran dari program unggulan "PIJAR" (sapi, jagung, dan rumput laut). Sementara, trend produksi kedelai tidak seperti jagung namun lebih fluktuatif bahkan cenderung menurun dengan rata-rata produksi mencapai 89,5 (x 000) ton per tahun. Fluktuasi produksi kedelai disebabkan karena harga kedelai belum dapat ditetapkan seperti halnya jagung sehingga minat petani untuk menanamnya cenderung menurun. Pemerintah memang menetapkan harga jagung cukup tinggi atas dasar produksi persatuan luas (hektar) sehingga banyak petani beralih menanam jagung dibandingkan dengan komoditas lainnya. Gambaran tentang produksi ketiga komoditas unggulan sebagaimana disajikan pada Gambar 4.

Gambar 4. Produksi Komoditas Pertanian (x 000 Ton)

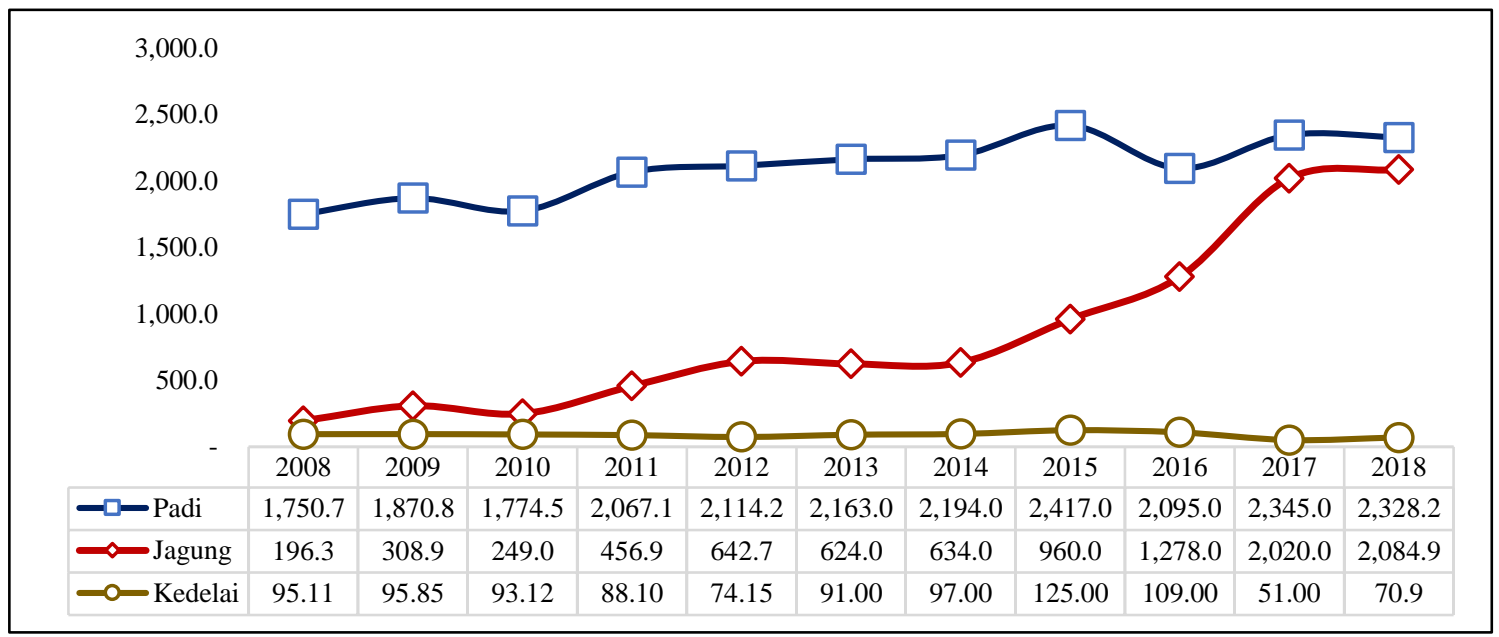

Sumber: BPS NTB (2008-2018)

Dilihat dari laju pertumbuhan, jagung memiliki laju pertumbuhan rata-rata 30,7 persen per tahun dengan prosentase tertinggi dicapai pada tahun 2011 ( 83,5 persen) dan terendah pada tahun 2010 (- 19,4 persen). Pada tahun 2009-2010, program PIJAR baru pada tahap implementasi dan pada periode berikutnya laju produksi mulai meningkat pesat. Prosentasi kenaikan komoditas jagung jauh lebih tinggi dibandingkan dengan padi ( 3,2 persen) dan kedelai $(0,8$ persen) pada periode yang sama. Gambar 5 di bawah menyajikan laju pertumbuhan ketiga komoditas selama kurun waktu 2008-2018

Gambar 5. Pertumbuhan Produksi Komoditas Pertanian (\%)

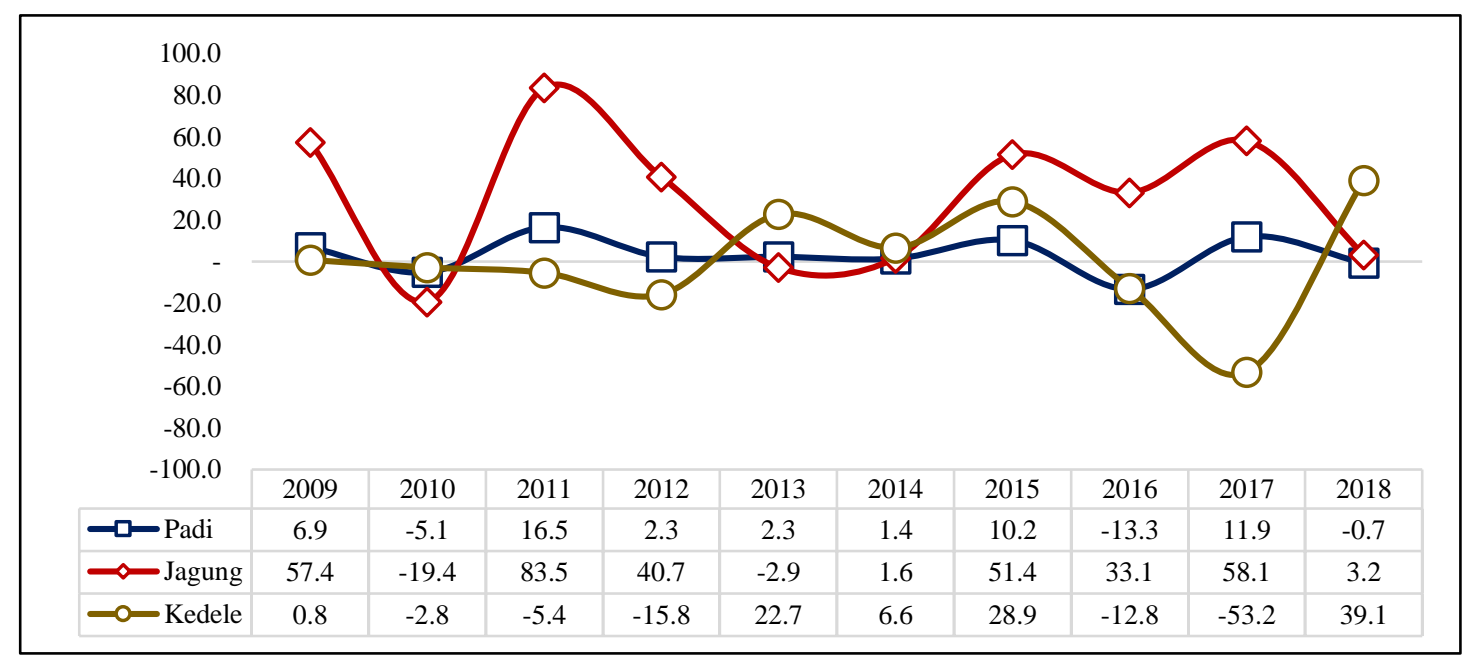

Sumber: BPS NTB (2008-2018)

Nilai Tukar Petani dan Angka Kemiskinan

Sayuti, R., H., dan Taqqiudin, M.

Volume 30 Nomor 1 April 2020 
Nilai Tukar Petani (NTP) merupakan satu-satunya indikator dalam menilai tingkat kesejahteraan petani secara relatif dilihat dari rasio antara harga yang diterima oleh petani dengan harga yang dibayar petani (lihat: Rahmat, 2013). Karena itu, NTP dinilai sebagai ukuran dalam menilai kemampuan daya beli/daya tukar petani terhadap barang yang dibeli sehingga pergerakan nilai NTP mengindikasikan tingkat kesejahteraan petani (Silitonga, 1995). Terdapat tiga kemungkinan NTP, yakni: NTP >100, petani surplus atau pendapatan petani lebih besar daripada pengeluaran; $\mathrm{NTP}=100$, petani mengalami impas atau pendapatan petani sama dengan pengeluarannya; NTP $<100$, petani mengalami defisit atau pendapatan petani turun, lebih kecil dari pengeluarannya. Pada periode 2008-2018, pola pergerakan NTP NTB dapat dibagi dua yakni: a) kurun waktu 2008-2013, NTP cenderun menurun dengan rata-rata penurunan 0,9 poin per tahun dan nilainya $<100$. Artinya, besaran pendapatan petani lebih kecil dari pengeluarannya; b) kurun waktu 2013-2018, NTP mulai naik dengan rata-rata kenaikan sebesar 2,9 poin per tahun dan mulai tahun 2015 NTP > 100 seiring dengan makin meningkatnya pendapatan petani. Perkembangan NTP NTB selama kurun waktu 2008-2018 ditunjukkan pada gambar 6 di bawah.

Gambar 6. Nilai Tukar Petani dan Angka Kemiskinan

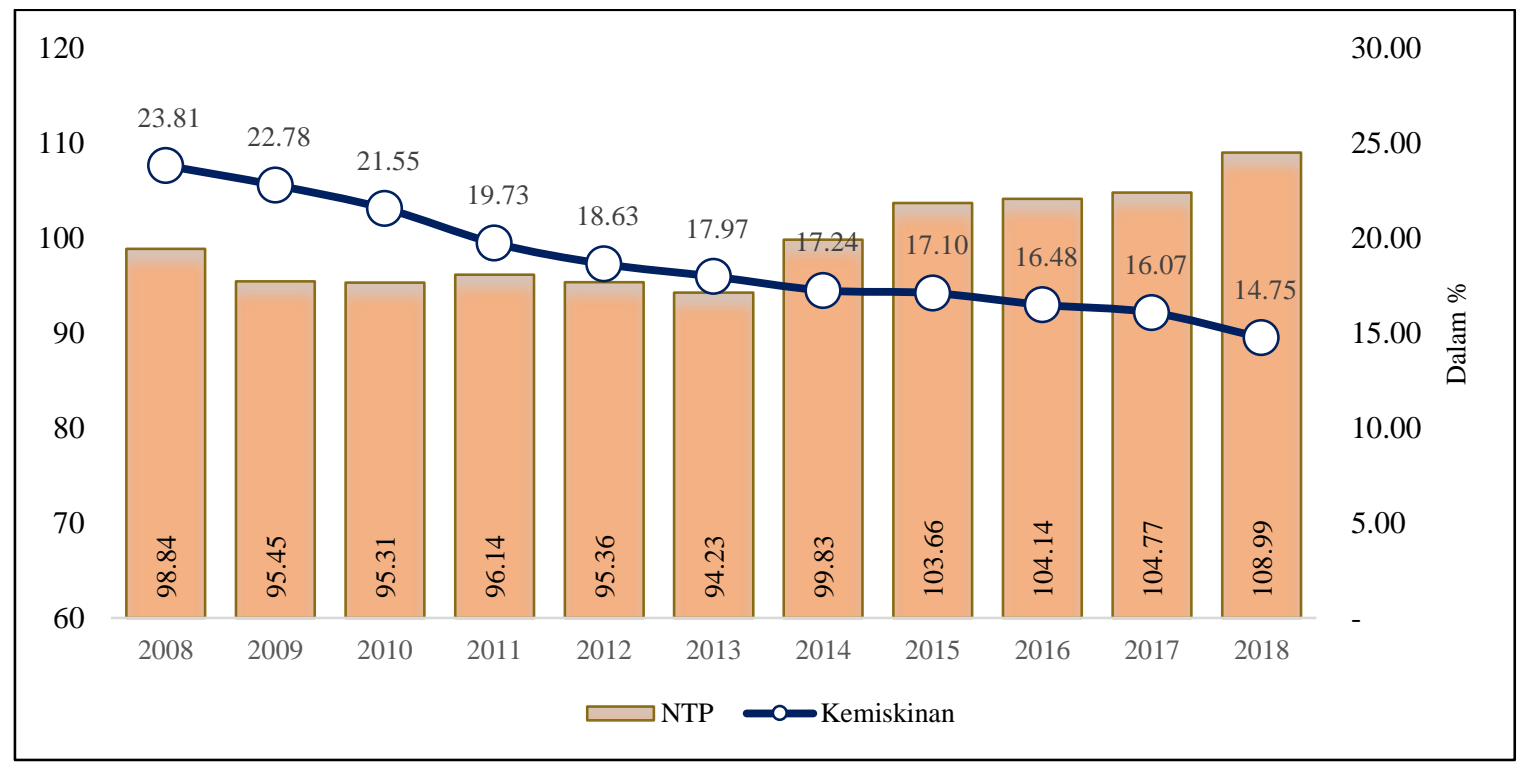

Sumber: BPS NTB (2008-2018)

Pada analisis selanjutnya, NTP sebagai indikator relatif kesejahteraan petani disandingkan dengan perkembangan penduduk miskin di NTB. Dalam kurun waktu 2008-2018, jumlah penduduk miskin NTB mengalami penurunan secara konsisten. Kecuali pada periode 2008-2013, tren penurunan angka kemiskinan NTB sejalan dengan peningkatan NTP terutama kurun waktu 2013-2018. Dengan analisis korelasi (SPSS), terlihat bahwa perkembangan NTP memiliki hubungan dengan perkembangan penduduk miskin $\left(r=-0,692 ; r^{2}=0,48\right.$; $\mathrm{p}<0,05)$. Artinya, peningkatan NTP terkait atau berhubungan dengan penurunan angka kemiskinan. Dengan kata lain, sekitar 48 persen variasi penduduk miskin NTB dijelaskan oleh NTP.

\section{KESIMPULAN DAN SARAN}

\section{Kesimpulan}

Dari kajian dan pembahasan di atas, maka dapat diambil kesimpulan sebagai berikut: a) Selama kurun waktu 2008-2018, dominasi struktur perekonomian NTB secara kumulatif mulai bergeser dari sektor primer ke sektor-sektor tersier sejalan dengan makin menurunnya kinerja sub-sektor pertambangan dan penggalian, namun demikian sub-sektor pertanian tetap menjadi basis perekonomian daerah; b) Kontribusi sektor pertanian (dalam arti luas) terhadap pembentukan PDRB NTB cenderung fluktuatif sebagai implikasi dari fluktuasi laju pertumbuhannya dengan rata-rata 3,7 persen per tahun ADHK 2010; c) Komoditas jagung memiliki laju pertumbuhan rata-rata 30,7 persen per tahun sejalan dengan implementasi program PIJAR atau jauh lebih tinggi dibandingkan dengan padi (3,2 persen) dan kedelai (0,8 persen) pada 2008-2018; d) Perkembangan NTP memiliki hubungan dengan perkembangan penduduk miskin, dimana peningkatan NTP terkait dengan penurunan angka kemiskinan atau 48 persen variasi penduduk miskin NTB dijelaskan oleh NTP. Dengan kata lain, penurunan angka kemiskinan di NTB dalam kurun waktu 2008-2018 adalah sebagai kontribusi dari suksesnya pembangunan pertanian, terutama program PIJAR, dimana jagung termasuk di dalamnya. 
Saran

Berdasarkan hasil analisis dan kesimpulan, maka saran untuk peningkatan kinerja sektor pertanian untuk pengentasan kemiskinan penduduk terutama kaitannya dengan produksi komoditas tanaman pangan adalah perlunya kebijakan perlindungan petani berupa penetapan harga seperti halnya pada komoditas jagung per satuan luas areal produksi (hektar). Dengan demikian, petani memiliki kepastian harga panen untuk berproduksi guna meningkatkan pendapatan mereka melalui makin tingginya Nilai Tukar Petani.

\section{DAFTAR PUSTAKA}

Chambers, R. 1983. Rural Development : Putting the Last First.London : Longman Group Ltd.

Hague, P.N., N. Hague and C.A. Morgan. 2013. Market research in practice: how to get greater insight from your market. The $2^{\text {nd }}$ Edition. KoganPage, London Philadelphia New Delhi.

Herbawati, Neneng, 2018. TGBNOMICS, Ikhtiar NTB untuk Indonesia. IGICo Advisory, Jakarta.

Martono, N. 2011. Metode Penelitian Kuantitatif: Analisis Isi dan Analisis Data Sekunder. RajaGrafindo Persada: Jakarta.

Purwanto, E.A. 2007. Mengkaji Potensi Usaha Kecil dan Menengah (UKM) untuk Pembuatan Kebiiakan Anti Kemiskinan di Indonesia. Jurnal llmu Sosial dan llmu Politik, Vol.10, No.3, Maret 2007.

Sayuti, Rosiady. 2017. Ikhtiar Mengindonesiakan NTB. Cetakan Kedua. Polidor, Yogyakarta.

Todaro, M.P. and S.C. Smith. 2015, Economic Development. 12 $2^{\text {th }}$ Edition. Pearson Ltd. New York.

Worldwide World Bank Organization, 2001. Retrieved from http://www.worldbank.org/en/topic/poverty

Yulaswati, V., M. Nanga, E. Fitrinika, D. Rahayuningsih, E. Dinayanti, F.M. Aulia, M. Rismalasari, M. Hafid, R. Wahyu, R.R. Putra, V. Kartika, Widaryanto. 2018. Analisis Wilayah dengan Kemiskinan Tinggi. Kedeputian Bidang Kependudukan dan Ketenagakerjaan Kementerian PPN/Bappenas. 